\title{
Impact of increasing levels of spineless-cactus meal on the ingestive behaviour of grazing steers
}

\section{Impacto do aumento dos níveis de farelo de palma forrageira sobre o comportamento ingestivo de novilhos em pastejo}

\author{
George Abreu Filho ${ }^{1 *}$; Robério Rodrigues Silva ${ }^{2}$; Fabiano Ferreira da Silva²; \\ Gleidson Giordano Pinto de Carvalho ${ }^{3}$; Maria Magna Silva Pereira ${ }^{1}$; \\ Fabrício Bacelar Lima Mendes ${ }^{4}$; Everton Santos Bastos; \\ Marceliana da Conceição Santos 5 ; Venício Macedo Carvalho ${ }^{6}$; \\ Túlio Otávio Jardim D’Almeida Lins ${ }^{4}$
}

\begin{abstract}
The objective of this study was to evaluate the effect of different levels of spineless-cactus meal substituting for maize in diets for supplemented steers grazing on Urochoa brizantha during the postweaning phase. The experiment was conducted on Princesa do Mateiro farm, located in Ribeirão do Largo-BA, Brazil. Forty crossbred steers with an average body weight of $261 \pm 7.46 \mathrm{~kg}$ were distributed into four groups for evaluation of the following four levels of substitution of ground maize for spinelesscactus meal: $0.00,30.00,60.00$, and $90.00 \%$. The results were analysed statistically by variance and regression analyses at a 5\% error probability. Increasing the amount of spineless-cactus meal in the diet had a quadratic effect on the grazing time and on the time spent on other activities. The diet had a quadratic effect on the number of grazing periods, the number of periods at the trough, and the total feeding and chewing times. In contrast, the number of periods spent on other activities and on rumination was not influenced by the level of spineless-cactus meal. The bite rate, number of bites per swallow, and number of bites per day increased linearly, whereas the swallowing time and number of cuds ruminated per day decreased as the level of spineless-cactus meal added to the diet wasincreased. The feed and rumination efficiencies of dry matter, neutral detergent fibre, crude protein, and non-fibre carbohydrates were not influenced by the level of substitution of spineless-cactus meal for ground maize. Spinelesscactus meal levels close to $60 \%$ probably provided greater fibre degradation, leading the animals to spend more time on social interactions with the group, use the feed better, and possibly have a better feed conversion.
\end{abstract}

Key words: Bites, bovine, pasture, production, ruminant, spineless cactus

\footnotetext{
${ }^{1}$ Discentes, Curso de Doutorado em Produção Animal, Universidade Estadual do Sudoeste da Bahia, UESB, Itapetinga, BA, Brasil. E-mail: georgeabreu16@hotmail.com; magnazootecnia@hotmail.com

2 Profs. Drs., Dept ${ }^{\circ}$ de Zootecnia da Universidade Estadual do Sudoeste da Bahia, UESB, Itapetinga, BA. Bolsista de produtividade do CNPq. E-mail: rrsilva.uesb@hotmail.com; ffsilvauesb@hotmail.com

${ }^{3}$ Prof. Dr., Dept ${ }^{\circ}$ de Zootecnia da Universidade Federal da Bahia, UFBA, Salvador, BA. Bolsista de Produtividade do CNPq, Brasil. E-mail: gleidsongiordano@yahoo.com.br

${ }^{4}$ Pós-Doutorandos em Produção Animal, UESPI, Corrente, PI e UESB, Itapetinga, BA, Brasil. E-mail: fabricio.bacelar@hotmail. com; tuliootavio@hotmail.com

${ }^{5}$ Discentes, Curso de Graduação em Zootecnia, UESB, Itapetinga, BA, Brasil. E-mail: everton-chapada@hotmail.com; marciazootec@hotmail.com

${ }^{6}$ Discente, Curso de Mestrado em Produção Animal, UESB, Itapetinga, BA. Brasil. E-mail: venicio_@hotmail.com

* Author for correspondence
} 


\title{
Resumo
}

\begin{abstract}
Objetivou-se avaliar os efeitos de diferentes níveis de substituição do milho pelo farelo de palma forrageira na dieta de novilhos mestiços sob suplementação em pastagens de Urochoa brizantha na fase de recria. O experimento foi conduzido na fazenda Princesa do Mateiro, no município de Ribeirão do Largo, Bahia. Foram utilizados 40 novilhos mestiços com peso corporal médio de 261 $\pm 7,46 \mathrm{~kg}$, distribuídos em quatro grupos, para avaliação de quatro níveis de substituição do milho moído pelo farelo de palma forrageira, 0,$00 ; 30,00 ; 60,00$; e $90,00 \%$. Os resultados foram analisados estatisticamente por meio de análise de variância e de regressão, a $5 \%$ de probabilidade de erro. $\mathrm{O}$ aumento da quantidade de farelo de palma na dieta provocou efeito quadrático no tempo de pastejo e no tempo destinado a outras atividades. Houve efeito quadrático da dieta sobre o número de períodos de pastejo, o número de períodos de cocho e para os tempos totais de alimentação e mastigação, ao contrário dos números de períodos destinados a outras atividades e à ruminação não foram influenciados pelos níveis de farelo de palma. A taxa de bocados, o número de bocados por deglutição e o número de bocados por dia aumentaram de forma crescente, enquanto o tempo de deglutição e o número de bolos ruminados por dia decresceram com o aumento dos níveis de farelo palma forrageira dieta. As eficiências de alimentação e ruminação da matéria seca, fibra em detergente neutro, proteína bruta e carboidratos não-fibrosos não foram influenciadas pelos níveis de substituição do milho moído pelo farelo de palma. Níveis próximos a $60 \%$ de farelo de palma forrageira provavelmente promoveu maior degradação da fibra, proporcionando aos animais mais tempo para a interação social entre o grupo, um melhor aproveitamento e possivelmente melhor conversão alimentar.
\end{abstract}

Palavras-chave: Bocados, bovino, palma forrageira, pasto, produção, ruminante

\section{Introduction}

Brazil is the world's second largest beef producer, with an estimated herd of 193.4 million head, exporting approximately 1.45 million tons in carcass weight equivalent (ANUALPEC, 2013). Rearing cattle on pastures is one of the most important activities of the country's economy, as approximately $90 \%$ of this production is obtained from pasture-finishing systems.

The Northeast region of Brazil has livestock as one of its main economic activities; however, this activity is compromised by the poor distribution of rainfall, shallow soils, and high temperatures, which result in low availability of feeds for animals in extensive systems. This is directly linked to the seasonality of this region, in which for the most part forage is available during the rainy season but this feedstuff becomes scarce in the dry season. These aspects reinforce the importance of and need for the use of feeding strategies for livestock farming in the semi-arid region, such as adequate planting and management of adapted forages (xerophiles) necessary to improve animal productivity and economic rates, and, especially, the sustainability of animal husbandry in this region. The great challenge of the livestock activity in the Brazilian Northeast semi-arid region is the sustainable use of the resources of the Caatinga biome (COUTINHO et al., 2013).

Spineless-cactus meal has been used as an alternative to meet the food deficit during periods of scarcity period and, according to Chiacchio et al. (2006), the great diversity in the use and application of the spineless cactus demonstrates the versatility of this species, which has not had its potentiality fully exploited, since a large fraction of producers do not have specific knowledge to potentiate its production to its maximum; this is a worrisome factor that generates minimum production and the false impression that this forage does not have productive potential. In addition, excellent opportunities to improve social indices are underestimated, e.g., the generation of employment and income, food supply, and environmental preservation.

One strategy to correct the qualitative deficiencies in the forage consumed by the 
animals, especially during times of food-shortage, is supplementation, which makes it an important alternative in optimizing the nutrients supplied by the basal diet, in addition to being an effective technology (EUCLIDES; MEDEIROS, 2005). With the need for feedstuffs to compose the concentrate diets in the grazing steers' supplementation system, spineless-cactus meal, with or without associated ground maize, soybean meal, cottonseed meal, and wheat bran, among others, can be a feasible alternative, though further research is necessary to better understand its utilization.

The cactus has approximately $10 \%$ dry matter and, after being processed to extract water, it can be used as an energy supplement, which facilitates the management of its supply to animals. The cactus meal has a low moisture content, and this feature is beneficial for the storage process, which lasts approximately six months under adequate conditions.

Because maize is one of the most widely utilized feedstuffs in animal feeding, also competing with human feeding, it is the object of many studies on animal nutrition aiming at its replacement with alternative feedstuffs. As spineless-cactus meal has appropriate nutritional quality, it can partially replace maize.

The structure of a pasture is an important characteristic that is related both to its morphophysiological traits and the ingestive behaviour of the grazing animals, since animals consuming mature forage, in general, spend more time ruminating to facilitate microbiological activity, which consequently reduces the time intended for consumption.

The study of animal behaviour makes it possible to evaluate the effects of feeding or the amount and nutritive quality of the feedstuffs and to establish the relationship between ingestive behaviour and voluntary intake, which thus allows for adjustment of the feeding management of the animals for better productive performance (MENDONÇA et al.,
2004). Another important aspect about observing behaviour is that it will enable the evaluation of the management practice adopted on the farm and, in some cases, behavioural alterations that may be the only indicator of stress (MEIRELES, 2005).

The objective of this study was to evaluate the effect of substituting ground maize for spinelesscactus meal on the ingestive behavior of crossbred steers during the post-weaning phase on Urochoa brizantha pastures.

\section{Material and Methods}

The experiment was conducted on Princesa do Mateiro farm, located in Ribeirão do Largo-BA, Brazil (15²6'46" S; 4044'24" W; 800 m altitude). The experimental period was 89 days, divided into three periods. Fourteen of these days were used for the animals to acclimate to the diets, and the remaining 75 days were the data-collection period; the first two periods lasted 28 days, and the last, due to lack of availability of the meal, lasted 19 days.

Forty Holstein $\times$ Zebu crossbred steers with an average initial weight of $261 \pm 7.46 \mathrm{~kg}$ were distributed in a completely randomized design with four levels of substitution of ground maize ( 0.00 , $30.00,60.00$, and $90.00 \%$ ) for spineless-cactus meal (treatments), with ten replicates per tested level. The animals were managed on a Urochoa brizantha cv. Marandu pasture with a total area of 13 ha, divided into 11 paddocks under rotational grazing.

Cultivar Miúda (Opuntia cochenillifera) was adopted for processing the spineless-cactus meal. The cactus was planted, harvested, and pre-dried in the city of Mirante-BA, Brazil. The pads were collected, finely sliced, and dried in open air for three consecutive days, in view of the dry climate of the region. After this period, the material was transported to Itapetinga-BA, where it was ground through a sieve with $3-\mathrm{mm}$ pores to generate the meal. Subsequently, the meal was incorporated by substituting for the maize according to its percentage 
of established levels of the other ingredients in the concentrate.

The supplementation was provided daily, at $10 \mathrm{~h} 00$, in collective plastic troughs (half water drums) with an approximate volume of $100 \mathrm{~L}$, measuring $70 \mathrm{~cm}$ animal-1, with double access and no cover.

The diets were formulated according to the NRC (2000) to meet the nutritional requirements of the animals so as to provide gains of $700 \mathrm{~g}^{\text {day }}{ }^{-1}$ (Table 1). The roughage:concentrate ratio in the diets was $73: 27$ for the level of $0.6 \%$ supplementation.

Table 1. Proportions of ingredients in the supplements as a percentage of dry matter (DM).

\begin{tabular}{lcccc}
\hline \multirow{2}{*}{ Ingredient } & \multicolumn{4}{c}{ Level of substitution (\%) } \\
\cline { 2 - 5 } & 0.00 & 30.00 & 60.00 & 90.00 \\
\hline Spineless-cactus meal & 0.00 & 23.89 & 47.90 & 72.07 \\
Maize & 79.92 & 55.97 & 31.89 & 7.69 \\
Soybean meal & 13.81 & 13.84 & 13.90 & 13.92 \\
Urea & 3.97 & 3.98 & 3.99 & 4.00 \\
Post-weaning salt $^{1}$ & 2.30 & 2.31 & 2.32 & 2.32 \\
\hline
\end{tabular}

${ }^{1}$ Composition: calcium 235 g; phosphorus 160 g; magnesium 16 g; sulphur 12 g; cobalt 150 mg; copper 1,600 mg; iodine 190 mg; manganese 1,400 mg; iron 1,000 mg; selenium $32 \mathrm{mg}$; zinc 6,000 mg; 1,120 mg; fluorine (maximum) 1,600 mg.

The pasture was evaluated on the first day of the experimental period and later, on average, every 28 days. To estimate the availability of DM, the direct method was employed, by throwing a square frame with an area of $0.25 \mathrm{~m}^{2}$ randomly over each paddock. Twelve samples were obtained, cut 5 $\mathrm{cm}$ above the soil level using appropriate shears, following the method described by McMeniman (1997) for the collection and determination of forage biomass, daily residual biomass (DRB), and daily accumulation rate. The forage allowance (FA) was calculated according to the following formula: $\mathrm{FA}=\{(\mathrm{DRB} \times$ area $+\mathrm{DAR} \times$ area $) /$ totalBW $\} \times 100$, where: $\mathrm{FA}=$ forage allowance, in $\mathrm{kg} \mathrm{DM} 100^{-1} \mathrm{~kg}$ $\mathrm{LW}$ day $^{-1}$; DRB = total residual biomass, in $\mathrm{kg}$ of $\mathrm{DM} / \mathrm{ha} /$ day; $\mathrm{DAR}=$ daily accumulation rate, in $\mathrm{kg}$ $\mathrm{DM} /$ ha/day; and $\mathrm{BW}=$ body weight of the animals, in $\mathrm{kg} / \mathrm{ha}$.

The potentially digestible dry matter (pDDM) of the pasture was determined according to the method described by Paulino et al. (2006) by the following equation: $\mathrm{pdDM}=0.98 \times(100-\% \mathrm{NDF})+(\% \mathrm{NDF}$ - \%iNDF).
The faecal production was estimated using LIPE $^{\circledR}$ (purified and enriched lignin) (SALIBA et al., 2000). One capsule was administered at a single dose per animal for seven days, with two days used for adaptation and regulation of the marker's flow, and five for faeces collection. The period of supply was from the 53rd to the 60th day of the experimental period. The following formula was utilized: $\mathrm{FP}=$ amount of LIPE ${ }^{\circledR}$ supplied $(\mathrm{g}) /((\mathrm{Ai} /$ total DM) $\times 100$, where: $\mathrm{FP}=$ faecal production; and $\mathrm{Ai}=$ logarithmic ratio of the intensity of absorption of the wavelength bands at $1050 \mathrm{~cm}^{-1} / 1650 \mathrm{~cm}^{-1}$.

Another external marker, titanium dioxide (TiO), was used to study the intake of dry matter (DM) from the concentrate (CDMI). The period of supply occurred together with the supply of LIPE ${ }^{\circledR}$, following the methodology described by Valadares Filho et al. (2006). Faeces were collected on the same days and times as described for the collection of $\mathrm{LIPE}^{\circledR}$. Equation: $\mathrm{CDMI}=(\mathrm{FE} \times \mathrm{TiO}$ feces $) / \mathrm{TiO}$ supplement, where: $\mathrm{TiO}$ faeces and $\mathrm{TiO}$ refers to the concentration of titanium dioxide in the faeces and supplement, respectively. 
To estimate the voluntary intake of roughage, the internal marker indigestible neutral detergent fibre (iNDF) was used. Samples of forage, faeces, and concentrate were incubated in the rumen of two cannulated animals for $288 \mathrm{~h}$ (TORRES et al., 2009) using non-woven fabric (TNT 100) bags, considering a ratio of $20 \mathrm{mg}$ sample $/ \mathrm{cm}^{2}$.

The collected samples feeds and faeces were conditioned in plastic bags and stored in a freezer at $-10^{\circ} \mathrm{C}$, and the analyses took place in the specialized laboratories of UESB. These were pre-dried in a forced-ventilation oven at $60^{\circ} \mathrm{C}$ and ground in a knife mill (1-mm sieve) for chemical analyses. Dry matter (DM), organic matter (OM), crude protein (CP), ether extract (EE), neutral detergent fibre (NDF), acid detergent fibre (ADF), non-fibre carbohydrates (NFC), cellulose, hemicellulose, lignin, and mineral matter (MM) contents were analysed according to the procedures described by Silva and Queiroz (2002). Following the methodology of Mertens (2002), the concentration of neutral detergent fibre corrected for ash and protein (NDFap) was determined. The concentration of non-fibre carbohydrates corrected for ash and protein (NFCap) was calculated as proposed by Hall (2003) as follows: NFCap $=(100$ - \%NDFap - \%CP - \%EE - \%ash).

The animals' ingestive behavior was evaluated for $96 \mathrm{~h}$, deducting the influence of the paddocks throughout the evaluation. At the end of every 24 $\mathrm{h}$ of evaluation, the animals were rotated over the paddocks, totalling three rotations until the end, with a half-hour interval after each rotation for the animals to resume their normal activities during the day. The steers were evaluated visually every $5 \mathrm{~min}$, following the methodology described by Silva et al. (2006).

The animals were identified by coloured ribbons tied around their necks, painted with different geometric shapes on strategic regions, and also by earrings. The following behavioural variables were studied: grazing time (GRZ, min day $^{-1}$ ), rumination time (RUM, min day ${ }^{-1}$ ), time feeding at the trough
(TRH, min day $\left.^{-1}\right)$, and time on other activities $\left(\mathrm{TRH}, \mathrm{min} \mathrm{day}^{-1}\right)$. The behavioural activities were considered mutually exclusive, as defined by Pardo et al. (2003).

The feed and rumination times were calculated as a function of the intakes of DM and NDF (min $\mathrm{kg}^{-1} \mathrm{DM}$ or NDF). The grazing time was considered the time spent by the animals to select and seize the forage, including the short time spaces utilized on the dislocation to select the forage (HANCOCK, 1953). The time used to ruminate corresponded to the processes of regurgitation, re-chewing, re-insalivation, and swallowing, while the time considered as feeding at the trough was the time spent by the animal consuming the supplement. The time on other activities (resting, water intake, social interactions, etc.) included all activities performed during the behavioural evaluation, except for the three others mentioned previously.

The discretization of time series was achieved by counting the discrete periods the animals used to feed, ruminate, and perform other activities. The average duration of each of the discrete periods was obtained by dividing the daily time spent on each of the activities by the number of discrete periods (SILVA et al., 2008).

The total feeding (TFT) and chewing (TCT) times were determined by the following equations: TFT $=$ GRZ + TRH, where: GRZ $(\mathrm{min})=$ grazing time; TRH $(\mathrm{min})=$ time spent feeding at the trough; $\mathrm{TCT}=\mathrm{GRZ}+\mathrm{RUM}+\mathrm{TRH}$, where GRZ $(\mathrm{min})=$ grazing time; RUM (min) = rumination time; TRH $(\min )=$ time spent feeding at the trough

The observations to determine the rumination chews and the time spent on the rumination of each cud were performed in two periods: in the morning $(10 \mathrm{~h} 00$ to $12 \mathrm{~h} 00)$ and in the afternoon (14h00 to 16h00) (BURGER et al., 2000).

The results of the observations of bites and swallowing, determined as the number of bites per day (NBD), expressed as the product between bite 
rate and grazing time, were recorded on six occasions for three days in the morning and afternoon periods, following the method described by Baggio et al. (2009).

To determine the bite rate (BTR), we adapted the methodology proposed by Hodgson (1982), by dividing the number of bites performed by each animal by the total time required to fill the oral cavity with the forage and subsequently swallow the cud, generated by the continuous collection of the pasture in certain feeding stations.

The variables number of cuds ruminated per day (NCD), time spent per rumination chew (TCh), and number of rumination chews per cud (NChC) were calculated by the following equations: $\mathrm{NCD}=$ RUM/TRC, where: NCD (n day $\left.{ }^{-1}\right)$; RUM (s day ${ }^{-1}$ ) rumination time; TRC (s) - time per ruminated cud; $\mathrm{TCh}=\mathrm{TRC} / \mathrm{NChC}$, where: TCh (s); TRC (s) - time per ruminated cud; $\mathrm{NChC}$ - number of rumination chews per cud; and $\mathrm{NChC}=\mathrm{NCD} \times \mathrm{NChD}$, where: NChC (n day ${ }^{-1}$ ); NCD - number of cuds ruminated per day; NChD - number of rumination chews per day.

The feed (FE) and rumination (RE) efficiencies of DM, NDF, NFC, and TDN were calculated according to the methodology of Burger et al. (2000).

The results were interpreted statistically by variance and regression analysis, at a 5\% error probability, using the System for Statistical and Genetic Analyses (Sistema de Análises Estatísticas e Genéticas - SAEG; UFV, 2001).

\section{Results and Discussion}

The total dry matter intake (TDMI), forage dry matter intake (FDMI), total intake of neutral detergent fibre corrected for ash and protein (TNDFapI), and total crude protein intake (TCPI) were not influenced by the substitution of ground maize for spineless-cactus meal in the supplement (Table 2).

A decreasing linear effect $(\mathrm{P}<0.05)$ occurred only on the intake of non-fibre carbohydrates (NFCI). This response may be explained by the smaller amount of this nutrient in the spineless-cactus meal as compared with the ground maize.

Increasing the level of spineless-cactus meal in the diet influenced the animals' grazing time, indicating a quadratic effect $(\mathrm{P}<0.05)$ with minima at $27.22 \%$ spineless-cactus meal substituting for the ground maize in the concentrate, with $463.74 \mathrm{~min}$ (Table 2). These results are probably a consequence of the molecular structure contained in the spineless cactus meal, formed by a large amount of pectin, which is highly degraded in the rumen. Gonçalves et al. (2009) state that this fraction can often potentiate forage digestibility. It is assumed that the pectin from the cactus had a greater fibre degradation speed in the rumen, and consequently provided greater colonization of cellulolytic bacteria, causing the animals to reduce their grazing time at substitution levels of up to $60 \%$. Substitution levels higher than $60 \%$ may generate an elevation in pasture intake, since the amount of energy required is probably not sufficient to meet the animals' requirement. 
Table 2. Intake of nutrients and ingestive behaviour of steers supplemented with a concentrate containing spinelesscactus meal substituting for maize.

\begin{tabular}{|c|c|c|c|c|c|c|c|c|c|}
\hline \multirow{2}{*}{ Item } & \multicolumn{4}{|c|}{ Level of substitution (\%) } & \multirow{2}{*}{$\mathrm{RE}$} & \multirow{2}{*}{ CV (\%) } & \multirow{2}{*}{$\mathrm{R}^{2}$} & \multicolumn{2}{|c|}{$P$} \\
\hline & 0.00 & 30.00 & 60.00 & 90.00 & & & & $\mathrm{~L}$ & Q \\
\hline TDMI (kg day $\left.{ }^{-1}\right)$ & 6.18 & 6.02 & 6.64 & 6.14 & $\hat{Y}=6.25$ & 17.71 & --- & 0.7075 & 0.5967 \\
\hline FDMI $\left(\mathrm{kg} \mathrm{day}^{-1}\right)$ & 4.36 & 4.44 & 4.86 & 4.41 & $\hat{\mathrm{Y}}=4.52$ & 23.02 & --- & 0.7489 & 0.4560 \\
\hline TNDFapI (kg day $\left.{ }^{-1}\right)$ & 3.03 & 3.22 & 3.64 & 3.48 & $\hat{\mathrm{Y}}=3.34$ & 20.16 & --- & 0.0798 & 0.4297 \\
\hline TCPI $\left(\mathrm{kg}\right.$ day $\left.^{-1}\right)$ & 0.79 & 0.79 & 0.81 & 0.70 & $\hat{\mathrm{Y}}=0.77$ & 14.88 & --- & 0.2119 & 0.1008 \\
\hline $\operatorname{NFCI}\left(\mathrm{kg} \mathrm{day}^{-1}\right)$ & 1.65 & 1.44 & 1.31 & 1.09 & 1 & 15.29 & 0.99 & 0.0000 & 0.7858 \\
\hline \multicolumn{10}{|c|}{ Min/day } \\
\hline GRZ & 471 & 482 & 461 & 516 & 2 & 9.86 & 0.50 & 0.0938 & 0.0010 \\
\hline OTH & 532 & 533 & 546 & 506 & 3 & 14.41 & 0.63 & 0.0478 & 0.0094 \\
\hline RUM & 399 & 380 & 396 & 381 & $\hat{\mathrm{Y}}=389$ & 14.05 & --- & 0.0779 & 0.6081 \\
\hline TRH & 38 & 45 & 37 & 37 & $\hat{\mathrm{Y}}=39$ & 37.23 & --- & 0.0749 & 0.4823 \\
\hline
\end{tabular}

TDMI = total dry matter intake; FDMI = forage dry matter intake; TNDFapI = total intake of neutral detergent fibre corrected for ash and protein; TCPI = total crude protein intake; NFCI = intake of non-fibre carbohydrates; GRZ = time spent grazing; OTH = time spent on other activities; RUM = time spent on rumination; TRH = time spent feeding at the trough.

$\mathrm{RE}=$ regression equation; $\mathrm{CV}=$ coefficient of variation, as a percentage; $\mathrm{R}^{2}=$ coefficient of determination; $\mathrm{L}=$ linear probability; $\mathrm{Q}=$ quadratic probability.

${ }^{1} \mathrm{Y}=1.6260-0.0058 \mathrm{X}$;

${ }^{2} \mathrm{Y}=478.1130-0.5280 \mathrm{X}+0.0097 \mathrm{X}^{2}$;

${ }^{3} \hat{Y}=527.3690+0.5730 X-0.0084 X^{2}$.

The time intended for other activities was influenced by the substitution of maize for the spineless-cactus meal $(\mathrm{P}<0.05)$. It was noted that levels of substitution above $60 \%$ were inversely proportional to the grazing time; thus, levels close to $60 \%$ substitution yielded better responses, possibly causing satiety in the animals, with faster degradation of the fibre and a stabilized rumen; in this way, the animals can spend more time resting, on social interactions, and doing other behavioural activities. Another factor associated with this behaviour is the properties of the supplied forage, whose nutritional quality and productive quantity are satisfactory.

No effect was found $(\mathrm{P}>0.05)$ on the times spent on rumination and feeding at the trough. The mean values for these variables were 389 and 39 min day $^{-}$ ${ }^{1}$, respectively, which shows that the digestibility of the pectin from the spineless-cactus meal and from the maize starch in the rumen was probably similar.

No significance was observed $(\mathrm{P}>0.05)$ for the time spent on consuming concentrate at the trough at all levels of substitution. The concentrate was always supplied in the same amount, corresponding to $0.6 \%$ of body weight for all animals.

The number of grazing periods (NGP) and the number of periods at the trough (NTP) had a quadratic response $(\mathrm{P}<0.05)$ (Table 3$)$.

The number of grazing periods (NGP) had its maxima at $37.5 \%$ substitution, with 11.86 , reflecting the grazing activity. This result was less than the 15.63 observed by Silva et al. (2010) using $0.6 \%$ supplementation for finishing steers, which indicates that the animals remained in more constant periods and used their feeding time better. 
Table 3. Number of periods and feeding times during behavioural activities performed by steers supplemented with a concentrate containing spineless-cactus meal substituting for maize.

\begin{tabular}{|c|c|c|c|c|c|c|c|c|c|}
\hline \multirow{2}{*}{ Item } & \multicolumn{4}{|c|}{ Level of substitution (\%) } & \multirow{2}{*}{$\mathrm{RE}$} & \multirow{2}{*}{ CV $(\%)$} & \multirow{2}{*}{$\mathrm{R}^{2}$} & \multicolumn{2}{|c|}{$\mathrm{P}$} \\
\hline & 0.00 & 30.00 & 60.00 & 90.00 & & & & $\mathrm{~L}$ & $\mathrm{Q}$ \\
\hline NGP & 13.85 & 12.20 & 13.40 & 14.70 & 1 & 26.55 & 0.98 & 0.1845 & 0.0132 \\
\hline NOP & 24.75 & 23.48 & 25.18 & 25.65 & $\hat{\mathrm{Y}}=25$ & 13.98 & --- & 0.7608 & 0.1481 \\
\hline NRP & 15.55 & 14.28 & 15.28 & 15.45 & $\hat{Y}=15$ & 15.65 & --- & 0.4749 & 0.7395 \\
\hline NTP & 4.08 & 4.35 & 4.25 & 3.50 & 2 & 34.91 & 0.48 & 0.7263 & 0.0111 \\
\hline TFT (min) & 507 & 537 & 497 & 553 & 3 & 8.98 & 0.54 & 0.2493 & 0.0004 \\
\hline TCT (min) & 870 & 872 & 857 & 897 & 4 & 8.73 & 0.61 & 0.0212 & 0.0141 \\
\hline
\end{tabular}

$\mathrm{NGP}=$ number of grazing periods; $\mathrm{NOP}=$ number of periods on other activities; $\mathrm{NRP}=$ number of rumination periods; $\mathrm{NTC}=$ number of periods feeding at the trough; TFT $=$ total feeding time; TCT $=$ total chewing time.

$\mathrm{RE}=$ regression equation; $\mathrm{CV}=$ coefficient of variation, as a percentage; $\mathrm{R}^{2}=$ coefficient of determination; $\mathrm{L}=$ linear probability; $\mathrm{Q}=$ quadratic probability.

${ }^{1} \mathrm{Y}=14.1190-0.0600 \mathrm{X}+0.0008 \mathrm{X}^{2}$

${ }^{2} \hat{Y}=4.0580+0.0200 X-0.0003 X^{2}$;

${ }^{3} \hat{Y}=516.975-0.3690 \mathrm{X}+0.0075 \mathrm{X}^{2}$;

${ }^{4} \hat{Y}=873.769-0.7310 \mathrm{X}+0.0011 \mathrm{X}^{2}$.

The number of periods feeding at the trough had its maxima at $33.33 \%$ spineless-cactus meal, averaging 4.72 , because of the amount of supplement received by all animals evaluated in the experiment, since high supplementation levels are consumed by the animals non-continuously, which leads to their searching for feed at the trough several times in a day, ultimately leading to differences in this activity.

The number of periods spent on other activities (NOP) and the number of rumination periods (NRP) were not influenced $(\mathrm{P}>0.05)$ by the level of substitution of ground maize for spineless-cactus meal. The number of rumination periods (NRP) is determined as the number of periods the animals spend reducing the fibre and it is directly correlated with the intake. Because no differences were found in the intake of NDFap between the different levels of substitution of maize for spineless-cactus meal, NRP was not influenced.

The levels of substation for the spineless-cactus meal had a quadratic effect $(\mathrm{P}<0.05)$ on the total feeding and chewing times. For the total feeding time, the minima was estimated at the level of $24.6 \%$ substitution, with $507.95 \mathrm{~min}$. The feeding time is related to the grazing activity and to the intake of supplement at the trough; thus, the more the animal eats, the higher will be its chewing frequency.

Another factor related to the total feeding and chewing times is the physical composition of the roughage and the concentrate. Because in this study the forage plant Urochoa brizantha was similar for all substitution levels, there were no differences $(\mathrm{P}>0.05)$ in forage intake, and so it can be stated that the concentrate interfered more expressively with the obtained results for performance.

The bite rate (BTR), the number of bites per swallow (NBSw), the time per swallow (TSw), the number of bites per day (NBD), and the number of cuds ruminated per day (NCD) increased linearly $(\mathrm{P}<0.05)$ with the inclusion of spineless-cactus meal in the diet (Table 4).

The bite rate increased with the inclusion of the meal, due to the greater amount of fibre present with the addition of the spineless-cactus meal, characterized by the interrelation between the animals' intake and the forage quality. This probably resulted in stimulation and greater proliferation of cellulolytic bacteria resulting from the fibre present 
in the spineless-cactus meal, which led to a rapid digestibility of the NDFap in the rumen. This high digestibility accelerates the passage rate and the emptying of the digestive tract, stimulating the animal to resume its grazing at shorter intervals and increase its bite rate, which in turn explains the increasing effect of the level of spineless-cactus meal in the diet on NBSw and NBD, since these factors are correlated with each other (BTR with NBSw and NBSw with NBD).

Table 4. Mean values for the behavioural variables of steers supplemented with a concentrate containing spinelesscactus meal substituting for maize.

\begin{tabular}{|c|c|c|c|c|c|c|c|c|c|}
\hline \multirow{2}{*}{ Item } & \multicolumn{4}{|c|}{ Level of substitution (\%) } & \multirow{2}{*}{$\mathrm{RE}$} & \multirow{2}{*}{ CV $(\%)$} & \multirow{2}{*}{$\mathrm{R}^{2}$} & \multicolumn{2}{|c|}{$\mathrm{P}$} \\
\hline & 0.00 & 30.00 & 60.00 & 90.00 & & & & $\mathrm{~L}$ & Q \\
\hline BTR (n) & 44 & 47 & 47 & 48 & 1 & 13.20 & 0.97 & 0.0123 & 0.6816 \\
\hline NBSw (n) & 22 & 20 & 21 & 22 & 2 & 8.52 & 0.99 & 0.0046 & 0.7621 \\
\hline $\mathrm{TSw}(\mathrm{s})$ & 31 & 25 & 28 & 28 & 3 & 14.28 & 0.99 & 0.0001 & 0.7777 \\
\hline NBD (days) & 20.751 & 23.360 & 21.581 & 24.734 & 4 & 16.24 & 0.59 & 0.3108 & 0.0202 \\
\hline $\mathrm{NCD}(\mathrm{n})$ & 543 & 505 & 590 & 500 & 5 & 17.58 & 0.95 & 0.0121 & 0.5791 \\
\hline $\mathrm{RChC}(\mathrm{n})$ & 47 & 50 & 45 & 49 & $\hat{Y}=48$ & 14.95 & --- & 0.5630 & 0.8379 \\
\hline TRCh (s) & 44 & 46 & 41 & 46 & $\hat{\mathrm{Y}}=44$ & 10.14 & --- & 0.0790 & 0.8540 \\
\hline
\end{tabular}

$\mathrm{BTR}=$ bite rate; $\mathrm{NBSw}=$ number of bites per swallow; $\mathrm{TSw}=$ time per swallow; $\mathrm{NBD}=$ number of bites per day; $\mathrm{NCD}=$ number of cuds ruminated per day; $\mathrm{RChC}=$ rumination chews per cud; $\mathrm{TRC}=$ time spent on rumination chews.

$\mathrm{RE}=$ regression equation; $\mathrm{CV}=$ coefficient of variation, as a percentage; $\mathrm{R}^{2}=$ coefficient of determination; $\mathrm{L}=$ linear probability;

$\mathrm{Q}=$ quadratic probability.

${ }^{1} \mathrm{Y}=44.9550+0.0370 \mathrm{X}$

${ }^{2} \hat{Y}=21.1350+0.0063 X$

${ }^{3} \hat{Y}=28.8830-0.0181 X$

${ }^{4} \hat{Y}=21.080 .8000+33.9050 X$

${ }^{5} \hat{Y}=541.5070-0.1570 X$.

The bite rate increased with the level of substitution of maize for the spineless-cactus meal. In a study with dairy cows under rotational grazing on millet fields, Mezzalira et al. (2013) obtained bite rates that varied from 38 to 42 , with a decreasing linear effect of the diet on this variable.

The inclusion of the spineless-cactus meal had a decreasing linear effect $(\mathrm{P}<0.05)$ on the variables TSw and NCD, probably due to the digestibility of the fibre offered to the animals that received higher levels of the meal. As a consequence, NCD decreased, probably because of the more accelerated microbial activity as compared with the activity of the control group.

The rumination chews per cud (RChC) and the time spent on rumination chews (TCh) did not show differences $(\mathrm{P}>0.05)$ between the levels of substitution of maize for spineless-cactus meal, probably as a result of the physical similarity of the diets.

The feed efficiencies of DM, NDF, CP, and NFC (Table 5) were 0.73, 0.39, 0.09, and 0.16, respectively, and the rumination efficiencies were $0.98,0.53,0.12$, and 0.22 . The feed efficiency represents the speed of ingestion of nutrients as a function of time (SANTANA JUNIOR et al., 2013). These variables were notably not influenced $(\mathrm{P}>0.05)$ by the level of substitution of ground maize for spineless-cactus meal, which may be related to the high and similar digestibility of maize and spineless-cactus meal, which showed similar efficiencies in the supplementation of cattle on pasture during the post-weaning phase. 
Table 5. Feed (FE) and rumination (RE) efficiencies of the dry matter in steers supplemented with concentrate containing spineless-cactus meal substituting for maize.

\begin{tabular}{|c|c|c|c|c|c|c|c|c|c|}
\hline \multirow{2}{*}{ Item } & \multicolumn{4}{|c|}{ Level of substitution (\%) } & \multirow{2}{*}{$\mathrm{RE}$} & \multirow{2}{*}{$\mathrm{CV}(\%)$} & \multirow{2}{*}{$\mathrm{R}^{2}$} & \multicolumn{2}{|c|}{$\mathrm{P}$} \\
\hline & 0.00 & 30.00 & 60.00 & 90.00 & & & & $\mathrm{~L}$ & Q \\
\hline & \multicolumn{4}{|c|}{ Feed efficiency $(\mathrm{kg} / \mathrm{h})$} & & & & & \\
\hline $\mathrm{FE}_{\mathrm{DM}}$ & 0.74 & 0.68 & 0.81 & 0.67 & $\hat{\mathrm{Y}}=0.73$ & 19.78 & --- & 0.4973 & 0.1169 \\
\hline $\mathrm{FE}_{\mathrm{NDF}}$ & 0.36 & 0.36 & 0.44 & 0.38 & $\hat{\mathrm{Y}}=0.39$ & 21.55 & --- & 0.5539 & 0.1793 \\
\hline $\mathrm{FE}_{\mathrm{CP}}$ & 0.09 & 0.09 & 0.10 & 0.08 & $\hat{\mathrm{Y}}=0.09$ & 18.04 & --- & 0.4448 & 0.0759 \\
\hline \multirow[t]{2}{*}{$\mathrm{FE}_{\mathrm{NFC}}$} & 0.20 & 0.16 & 0.16 & 0.12 & $\hat{\mathrm{Y}}=0.16$ & 19.02 & --- & 0.4402 & 0.0614 \\
\hline & \multicolumn{4}{|c|}{ Rumination efficiency (kg/h) } & & & --- & & \\
\hline $\mathrm{RE}_{\mathrm{DM}}$ & 0.95 & 0.96 & 1.03 & 0.99 & $\hat{\mathrm{Y}}=0.98$ & 23.71 & --- & 0.3773 & 0.8100 \\
\hline $\mathrm{RE}_{\mathrm{NDF}}$ & 0.47 & 0.51 & 0.57 & 0.56 & $\hat{\mathrm{Y}}=0.53$ & 25.40 & --- & 0.4147 & 0.8437 \\
\hline $\mathrm{RE}_{\mathrm{CP}}$ & 0.12 & 0.13 & 0.12 & 0.11 & $\hat{\mathrm{Y}}=0.12$ & 21.05 & --- & 0.3213 & 0.7049 \\
\hline $\mathrm{REN}_{\mathrm{FC}}$ & 0.25 & 0.23 & 0.20 & 0.18 & $\hat{\mathrm{Y}}=0.22$ & 21.49 & --- & 0.3155 & 0.6136 \\
\hline
\end{tabular}

$\mathrm{DM}=$ dry matter; $\mathrm{NDF}=$ neutral detergent fibre $\mathrm{CP}=$ crude protein; $\mathrm{NFC}=$ non-fibre carbohydrates.

$\mathrm{RE}=$ regression equation; $\mathrm{CV}=$ coefficient of variation, as apercentage; $\mathrm{R}^{2}=$ coefficient of determination; $\mathrm{L}=$ linear probability;

$\mathrm{Q}=$ quadratic probability.

\section{Conclusions}

Levels close to $60 \%$ of spineless-cactus meal probably provided a greater degradation of the fibre, leading the animals to spend more time on social interactions with the group, use the feed better, and possibly have a better feed conversion.

Increasing the levels of spineless-cactus meal elevated the bite rate, the number of bites per swallow, the time per swallow, the number of bites per day, and the number of cuds ruminated per day, but it did not interfere with the feed or rumination efficiencies.

\section{References}

ANUALPEC. ANUÁRIO DA PECUÁRIA BRASILEIRA. São Paulo: Informa Economics FNP, 2013.

BAGGIO, C.; CARVALHO, P. C. F.; SILVA, J. L. S.; ANGHINONI, I.; LOPES, M. L. T.; THUROW, J. M. Padrões de deslocamento e captura de forragem por novilhos em pastagem de azevém-anual e aveia-preta manejada sob diferentes alturas em sistema de integração lavoura-pecuária. Revista Brasileira de Zootecnia, Viçosa, MG, v. 38, n. 2, p. 215-222, 2009.
BURGER, P. J.; PEREIRA, J. C.; QUEIROZ, A. C.; SILVA, J. F. C.; VALADARES FILHO, S. C.; CECON, P. R.; CASALI, A. D. P. Comportamento ingestivo de bezerros holandeses alimentados com dietas contendo diferentes níveis de concentrado. Revista Brasileira de Zootecnia, Viçosa, MG, v. 29, n. 1, p. 236-242, 2000.

CHIACCHIO, F. P. B.; MESQUITA, A. S.; SANTOS, J. R. Palma forrageira: uma oportunidade econômica ainda desperdiçada para o semiárido baiano. Bahia Agrícola, Salvador, v. 7, n. 3, p. 39-49, nov. 2006.

COUTINHO, M. J. F.; CARNEIRO, M. S. S.; EDVAN, R. L.; PINTO, A. P. A pecuária como atividade estabilizadora no Semiárido Brasileiro. Veterinária e Zootecnia, Botucatu, v. 3, n. 20, p. 9-17, 2013.

EUCLIDES, V. P. B.; MEDEIROS, S. R. Suplementação animal em pastagens e seu impacto na utilização da pastagem. In: SIMPÓSIO SOBRE O MANEJO DA PASTAGEM, 22., 2005, Piracicaba. Anais... Piracicaba: FEALQ, 2005. p. 33-70.

GONÇALVES, L. C.; BORGES, I.; FERREIRA, P. D. S. Alimentos para gado de leite. Belo Horizonte: FEPMVZ, 2009. $568 \mathrm{p}$.

HALL, M. B. Challenges with non-fiber carbohydrate methods. Journal of Animal Science, Champaign, v. 81, n. 12 , p. 3226-3232, 2003.

HANCOCK, J. Grazing behaviour of cattle. Animal Breeding Abstract, Wallingford, v. 21, n. 1, p. 1-13, 1953. 
HODGSON, J. Ingestive behavior. In: LEAVER, J. D. (Ed.). Herbage intake handbook. Hurley: British Grassland Society, 1982. p. 113.

McMENIMAN, N. P. Methods of estimating intake of grazing animals. In: REUNIÃO ANUAL DA SOCIEDADE BRASILEIRA DE ZOOTECNIA, SIMPÓSIO SOBRE TÓPICOS ESPECIAIS EM ZOOTECNIA, 34., 1997, Juiz de Fora. Anais... Juiz de Fora: Sociedade Brasileira de Zootecnia, 1997. p. 131168.

MEIRELES, I. P. Influência do sombreado em parâmetros fisiológicos e produtivos de vacas mestiças (holandês $x$ zebu). 2005. Dissertação (Mestrado em Zootecnia) Universidade Estadual do Sudoeste da Bahia, Itapetinga.

MENDONÇA, S. S.; CAMPOS, J. M. S.; VALADARES FILHO, S. C.; VALADARES, R. F. D.; SOARES, C. A.; LANA, R. P.; QUEIROZ, A. C.; ASSIS, A. J.; PEREIRA, M. L. A. Comportamento ingestivo de vacas leiteiras alimentadas com dietas à base de cana-de-açúcar ou silagem de milho. Revista Brasileira de Zootecnia, Viçosa, MG, v. 33, n. 3, p. 723-728, 2004.

MERTENS, D. R. Gravimetric determination of amylase treated neutral detergent fiber in feeds with refluxing in beaker or crucibles: collaborative study. Journal of AOAC International, Madinson, v. 85, n. 6, p. 1217-1240, 2002.

MEZZALIRA, J. C.; CARVALHO, P. C. F.; AMARAL, M. F.; BREMM, C.; TRINDADE, J. K.; GONÇALVES, E. N.; GENRO, T. C. M.; SILVA, R. W. S. M. Manejo do milheto em pastoreio rotativo para maximizar a taxa de ingestão por vacas leiteiras. Arquivo Brasileiro de Medicina Veterinária e Zootecnia, Belo Horizonte, v. 65, n. 3, p. 833-840, 2013.

NATIONAL RESEARCH COUNCIL - NRC. Nutrient requirements of beef cattle. $7^{\text {th }}$ ed. rev. Washington, DC.: National Academy Press, 2000. 242 p.

PARDO, R. M. P.; FISCHER, V.; BALBINOTTI, M.; MORENO, C. B.; FERREIRA, E. X.; VINHAS, R. I.; MONKS, P. L. Comportamento ingestivo diurno de novilhos em pastejo submetidos a níveis crescentes de suplementação energética. Revista Brasileira de Zootecnia, Viçosa, MG, v. 32, n. 6, p. 1408-1418, 2003.

PAULINO, M. F.; DETMANN, E.; VALADARES FILHO, S. C. Suplementação animal em pasto: energética ou protéica? In: SIMPÓSIO SOBRE MANEJO ESTRATÉGICO DA PASTAGEM, 3., 2006, Viçosa, MG. Anais... Viçosa, MG: SIMFOR, 2006. p. 359-392.
SALIBA, E. O. S.; NANJARO, A.; FERREIRA, W. M.; RODRIGUES, N. M.; VELOSO, D. P.; CAPANELA, E.; SALIBA, M. S. Avaliação da lignina de madeira moída do Pinus e da lignina purificada e enriquecida do Eucaliptus grandis (Lipe ${ }^{\circledR}$ ), como indicadores externos em experimentos de digestibilidade aparente para coelhos em crescimento. In: REUNIÃO ANUAL DA SOCIEDADE BRASILEIRA DE ZOOTECNIA, 37., 2000, Viçosa, MG. Anais... Viçosa: SBZ, 2000. CDROM.

SANTANA JÚNIOR, H. A.; SILVA, R. R.; CARVALHO, G. G. P.; CARDOSO, E. O.; MENDES, F. B. L.; PINHEIRO, A. A.; ABREU FILHO, G.; DIAS, D. L. S.; BARROSO, D. S.; SILVA, F. F.; TRINDADE JUNIOR, G. Comportamento ingestivo de novilhas suplementadas a pasto sob nutrição compensatória. Archivos de Zootecnia, Cordoba, v. 62, n. 237, p. 61-71, 2013.

SILVA, D. J.; QUEIROZ, A. C. Análise de alimentos: métodos químicos e biológicos. Viçosa: Universidade Federal de Viçosa, MG, 2002. 235 p.

SILVA, R. R.; PRADO, I. N.; CARVALHO, G. G. P.; SANTANA JUNIOR, H. A.; SILVA, F. F.; DIAS, D. L. S. Efeito da utilização de três intervalos de observações sobre a precisão dos resultados obtidos no estudo do comportamento ingestivo de vacas leiteiras em pastejo. Ciência Animal Brasileira, Goiânia, v. 9, n. 2, p. 319326, abr./jun. 2008.

SILVA, R. R.; PRADO, I. N.; SILVA, F. F.; ALMEIDA, V. V. S.; SANTANA JUNIOR, H. A.; QUEIROZ, A. C.; CARVALHO, G. G. P.; BARROSO, D. S. Comportamento ingestivo diurno de novilhos Nelore recebendo níveis crescentes de suplementação em pastejo de capimbraquiária. Revista Brasileira de Zootecnia, Viçosa, MG, v. 39, n. 9, p. 2073-2080, 2010.

SILVA, R. R.; SILVA, F. F.; PRADO, I. N.; CARVALHO, G. G. P.; FRANCO, I. L.; ALMEIDA, V. S.; CARDOSO, C. P.; RIBEIRO, M. H. S. Comportamento ingestivo de bovinos. Aspectos metodológicos. Archivos de Zootecnia, Córdoba, v. 55, n. 211, p. 293-296, 2006.

SISTEMA PARA ANÁLISE ESTATÍSTICA E GENÉTICA - SAEG. Universidade Federal de Viçosa, Central de processamento de dados. Viçosa, MG: UFV, $2001.301 \mathrm{p}$.

TORRES, L. C. L.; FERREIRA, M. A.; GUIM, A.; VILELA, M. S.; GUIMARÃES, A. V.; SILVA, E. C. Substituição da palma-gigante por palma-miúda em dietas para bovinos em crescimento e avaliação de indicadores internos. Revista Brasileira de Zootecnia, Viçosa, MG, v. 38, n. 11, p. 2264-2269, 2009. 
VALADARES FILHO, S. C.; MORAES, E. H. B. K.; DETMANN, E.; PAULINO, M. F.; VALADARES, R. F. D.; MORAES, K. A. K.; MARCONDES, M.

I. Perspectivas do uso de indicadores para estimar o consumo individual de bovinos alimentados em grupo. In: SIMPÓSIO DA REUNIÃO ANUAL DA SOCIEDADE BRASILEIRA DE ZOOTECNIA, 43., 2006, João Pessoa. Anais... João Pessoa: SBZ, UFPB, 2006. p. 238-262. 